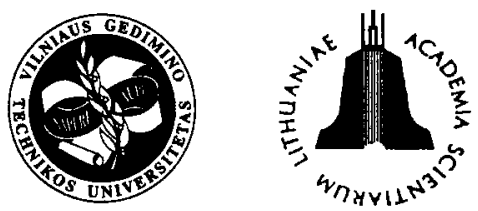

JOURNAL OF CIVIL ENGINEERING AND MANA

http:/www.vtu.li/cnglish/cditions

2002, Vol VIII, No 3, 206-213

\title{
REGULARITIES OF DEFECT DEVELOPMENT IN THE ASPHALT CONCRETE ROAD PAVEMENTS
}

\author{
Henrikas Sivilevičius ${ }^{1}$, Kazys Petkevičius ${ }^{2}$ \\ ${ }^{1}$ Dept of Transport Technology Equipment. E-mail: tti@ti.vtu.lt ${ }^{2}$ Dept of Road Engineering, \\ Vilnius Gediminas Technical University, Sauletekio al.11,LT-2040Vilnius, Lithuania. E-mail: keliukat@ap.vtu.lt
}

\author{
Received 06 Feb 2001; accepted 15 May 2002
}

\begin{abstract}
A new classification of asphalt concerete pavement defects is presented in the article and the causes of their development are systematised. The dynamics of asphalt concrete pavement defect development in the road and the dependence of pavement deterioration on the type of defects are presented in the theoretical graphic model. The change of road pavement structural strength (stiffness modulus) depending on the pavement service life is also described. The dependence of the level of asphalt concrete pavement on the most important roads of the Republic of Lithuania (road Vilnius-Kaunas [A1] and motorway Vilnius-Panevezžys [A2]) measured with one-wheel dynamometric trailer PKRS-2U (Russia) on the level of pavement deterioration has been identified through experiments. The analysis of the dependence of transport costs and driving speed on road pavement level has been carried out. Regression equations of such dependence and correlation coefficients as well as relations are presented too.
\end{abstract}

Keywords: asphalt concrete pavement, pavement defect, pavement deterioration, pavement service life, pavement roughness, transport costs, driving speed of vehicles.

\section{Introduction}

Lithuanian road and street pavements are mostly of asphalt concrete, the properties of which change depending on the loads of vehicles and climatic factors. Reduction of asphalt concrete strength and the weight of vehicles as well as constant increase of traffic volumes result in rapid deterioration of road pavement wearing course. Road or its separate section deterioration is caused by numerous factors, the impact of which is difficult to estimate [1-6]. The actual strength of asphalt concrete pavement can be estimated by well-known experimental methods. Due to their complexity, high price, low efficiency, heavy work load, lack of dependable mobile laboratory equipment, insufficient qualification of specialists carrying out research as well as inefficient usage of research findings, in most cases it is difficult to give dependable answers to practical questions. In most cases, it is difficult to estimate the service life of pavement at higher or lower traffic volumes; when cracks, depressions (potholes) and other defects will form on the road; how intensively they will increase; what measures (technologies, materials, equipment, etc) and when shall be taken to prolong the pavement service life using the existing resources effectively.

Practically no preventive measures are taken to prolong the service life of pavement on separate road sections since it is not clear when and in what concrete spots a crack will appear or the pavement will start to break into pieces, and how long it will take for the pothole to develop. The service life of the pavement on the whole road or a relatively long road section is prolonged by roughening the pavement by surface dressing, laying a new asphalt concrete layer, entirely regenerating the pavement or using any other well-known method. In most cases, cracks or potholes in asphalt concrete pavement are repaired only when their contours become clear and when these defects become dangerous for traffic.

This work aims to classify road asphalt concrete pavement defects, to identify the reasons, dynamics of their development, to show how pavement deterioration depends on the strength of road pavement, vehicles driving speed and transport costs on pavement deterioration, as well as to present allowable values of Lithuanian motorways' asphalt concrete pavement and its structural parameters.

\section{The type and classification of asphalt concrete pave- ment}

The are different classifications of defects in asphalt concrete pavement since each classification is conditional and depends on selected evaluation criteria. In our opinion, asphalt concrete defects could be classified according to the following features: 


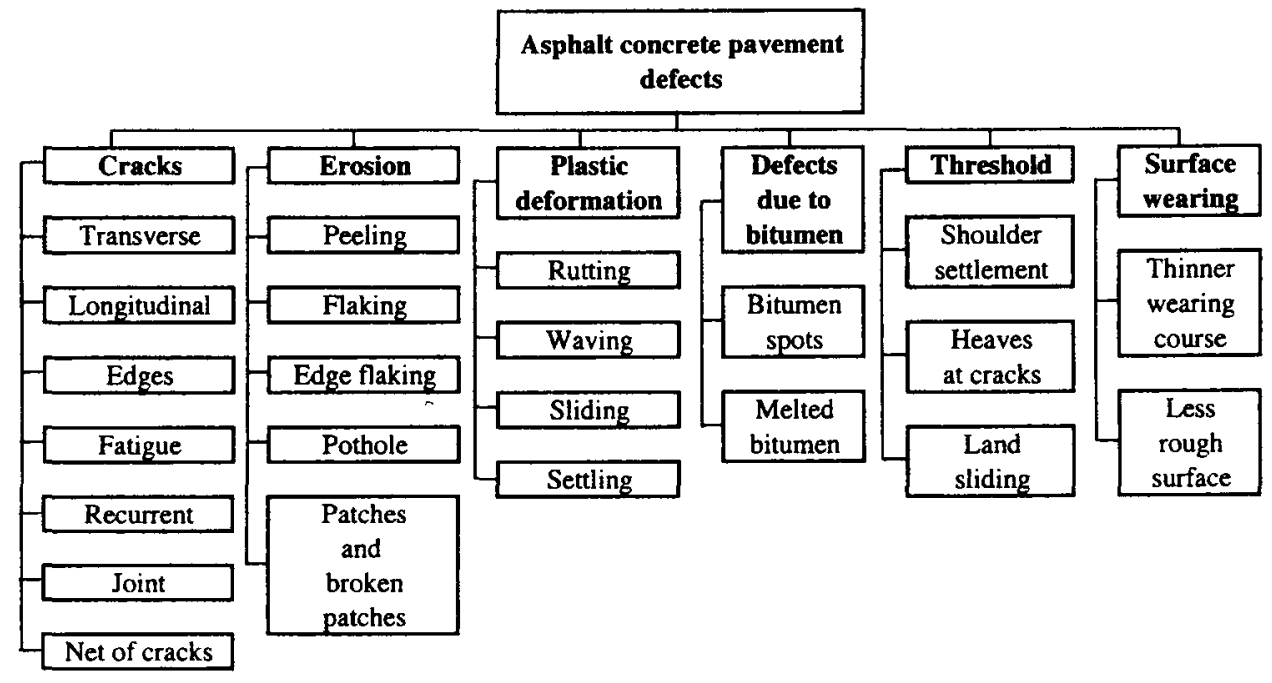

Fig 1. The classification of asphalt concrete road cover defects fects,

- the type of factors influencing formation of deface,

- the type of defects forming on the pavement sur-

- the size of defects (level of pavement deterioration),

- the type of materials suitable for defect correction.

Asphalt concrete pavement defects are mostly classified according to the form of defects (shape and size). Traditionally, they are classified into groups. A new classification (more comprehensive) of defects is presented in Fig 1.

There are three levels of complete formation of defects: low, medium and high.

\section{Reasons of defect formation in asphalt concrete pavement}

In most cases, the first cracks in pavement and its flaking (surface erosion) as well as potholes develop in several years after the road is paved. Later, formation of pavement defects becomes more intensive: cracks become wider and deeper, the area of pavement spots broken by erosion as well as volume of potholes increase; therefore, defects which were not removed on time reach a critical level.

We recommend to estimate the deterioration scale of road asphalt concrete pavement expressed in per cent by deterioration level $D$ :

$$
D=\left(S_{d}+S_{p l}+S_{p}+S_{p r}+S_{n}+\sum_{i=1}^{n} l_{i} b_{i}\right) \cdot 100 / S,
$$

$S_{d}$ is the area of patched pavement broken by cracking, flaking, edge flaking, potholes, landsliding and patched areas of pavement in an investigated road section in $\mathrm{m}^{2}$; $S_{p l}$ - area of pavement broken by the net of cracks in $\mathrm{m}^{2} ; S_{p}-$ area of pavement broken by plastic deformations: rutting, waving, sliding, landsliding in $\mathrm{m}^{2} ; S_{p r}$ pavement broken by surface defects: bitumen spots as well as melted bitumen spots in $\mathrm{m}^{2} ; S_{n}$ - pavement broken by surface wear; thinner wearing course spots in $\mathrm{m}^{2} ; l_{i}$ - length of separate $i$ crack in $\mathrm{m} ; b_{i}$ - width of the pavement lane having lost strength from both sides of $i$ crack, depending on the crack width in $\mathrm{m} ; S$-area of asphalt concrete pavement of road section under investigation in $\mathrm{m}^{2}$.

Our tests showed [7] that index $D$ is closely related to the roughness of pavement $Y$ and the strength of its construction defined as stiffness modulus $K$. Index $K$ is calculated by the formula

$$
K=\frac{E_{f}}{E_{r}}
$$

where $E_{f}$ is factual elasticity modulus of road pavement structure at the moment of its weakest condition $\mathrm{MPa} ; E_{r}$ - required elasticity modulus of pavement structure MPa.

Research findings showed that the higher the road pavement defect values, the lower is $K$ : when the road pavement condition is good and satisfactory, defects make up $0-15 \%$ of pavement area $(K \geq 1)$, and when the road pavement condition is bad, defects make up $50-70 \%$ of pavement area $(K<0,8)[8]$.

When stiffness modulus is low, deformations and deteriorations reducing dependability of the road pavement structure develop. When the strength of pavement structure is uniform, parameter $K$ fluctuates inconsiderably around the average value: it reduces probability of defect formation and increases dependability of road pavement. Pavement structural uniformity can be evaluated by the average quadratic deviation of actual modulus of elasticity $\sigma_{E}$ or variation coefficient $V_{E}$ : 


$$
V_{E}=\sigma_{E_{f}} 100
$$

$E_{f}$ is the average value of road pavement construction actual modulus of elasticity (arithmetical mean).

When there are no cracks or very few of them: $V_{E} \leq 20 \%$, and considerable pavement defects form (potholes, waves, wide and deep cracking, etc): $V_{E} \geq 55 \%$ [8].

The best service life characteristics are typical of a newly paved road. When driving on the road, its geometrical parameters (carriage way, shoulders, median and road earth bank widths, cross falls, etc) change inconsiderably. Road pavement directly influenced by vehicle wheels and climatic factors constantly change their properties when pavement surface wears: wearing asphalt concrete course becomes thinner and sharp edges of particles on the pavement surface are polished; therefore, pavement strength, roughness and traffic safety on the road decrease. Due to vertical and horizontal periodical wheel loads the pavement fatigues. Fatigue causes elastic and plastic deformations and, in the course of time, fatigue cracking. Cracking and rutting as well as other deformations develop intensively and pavement uniformity decreases, wheel loads become dynamic. It results in the following considerable impacts: reduction of driving comfort and traffic safety as well as intensive deterioration of the weakest spots on pavement. All those deformations are seasonal $t_{s e z}$ : during each flood season in spring $t_{p o l}$ the strength of pavement construction decreases (elasticity modulus $E_{f}$ ), temperature (transverse) and other cracks as well as pavement surface cracking increase. Reduction dynamics of road pavement structural strength is presented in our theoretical model (Fig 2). 'Toothed' curve illustrating stiffness modulus $K$ reduction with constantly increasing strength changes reflects our principal belief that weaker road pavement structure sections fatigue quicker.

Climatic factors change asphalt concrete structure (from elastically fragile to elastically plastic or vice versa): it pulls away or brings closer imported filler in the monolith, weakens adhesion of imported filler with bitumen, changes bitumen volume, ages bitumen (increases viscosity and reduces elasticity), weakens adhesion of bitumen molecules (cohesion) and weakens foundations. Due to this, the strength, deformation, dependability and service life of road pavement structures, as homogeneous systems, decrease.

The technological process of asphalt concrete laying is very complicated. Deviations from technical specifications and research methods' standard requirements, optimal designing techniques, recommended technologies of asphalt concrete mixture production, specifications of its storage, transportation, laying and compaction operations affect the characteristics and indicators of the pavement quality. The strongest asphalt concrete pavement of the longest service life can be laid only if the highest level characteristics of technological operations are guaranteed.
Since properties of materials and parameters of asphalt concrete mixture production, technological operations of construction and compaction continuously change and are stochastic, the constructed pavement is not uniform in terms of its characteristics. Asphalt concrete mineral part grading, void content, the degree of compaction and other physical parameters, bitumen quantity and properties of materials used for asphalt concrete mixture production as well as the thickness of asphalt concrete fluctuate at rather wide intervals; therefore, mechanical properties of pavement are not the same. In some pavement areas asphalt concrete is much weaker than in the adjacent ones where its actual strength exceeds the required strength considerably.

Due to inhomogeneity of road pavement, asphalt concrete does not deteriorate on the whole area of pavement. The less uniform the pavement is, the earlier its separate areas can start deteriorating; therefore, it shall be repaired sooner. Climatic factors and their impact on the pavement are not the same as well. In the beginning of winter, snow is usually ploughed from the carriageway to shoulders and slopes of the embankment; therefore a thermal insulation layer of certain thickness is laid, and the road pavement cools sooner. When the clay of the embankment soil bloats with dampness, the road pavement can rise and crack inhomogeneously; therefore, longitudinal cracks can appear in the pavement $[8,9]$. In spring, exposed to the hot sun, the middle of the road carriageway heats earlier than the pavement at road shoulders; therefore, when the zone of pavement, which has risen due to cooling settles down inhomogeneously and the cracks widen and are filled with water, clay, residual dust, particles of imported fillers as well as asphalt concrete.

\section{Dynamics of defect formation in asphalt concrete pavement}

Asphalt concrete is a material with reverse changes of microstructural location reflecting quantitative relation of bitumen and mutual impact on imported fillers, the most disperse (finest) and most active asphalt concrete constituent, which can be of various states: elastic friable, elastic plastic, and viscous plastic.

Asphalt concrete on the pavement of Lithuanian roads is affected not only by wheels but also by temperature and its fluctuations. Due to this, asphalt concrete cools to $>30^{\circ} \mathrm{C}$ and heats up to $>+60^{\circ} \mathrm{C}$; precipitation and flood water, which permeates into pores (voids) and weakens cohesion of imported fillers with bitumen film, bloating clay particles, and when cooled, expands and pulls some particles from other forming internal microcracks. Under our climatic conditions, road pavement temperatures change from positive to negative and vice versa $70-80$ or more times a year. Such frequent change destroys saturated porous road pavement structure layers reinforced with bitumen or other organic binders. 


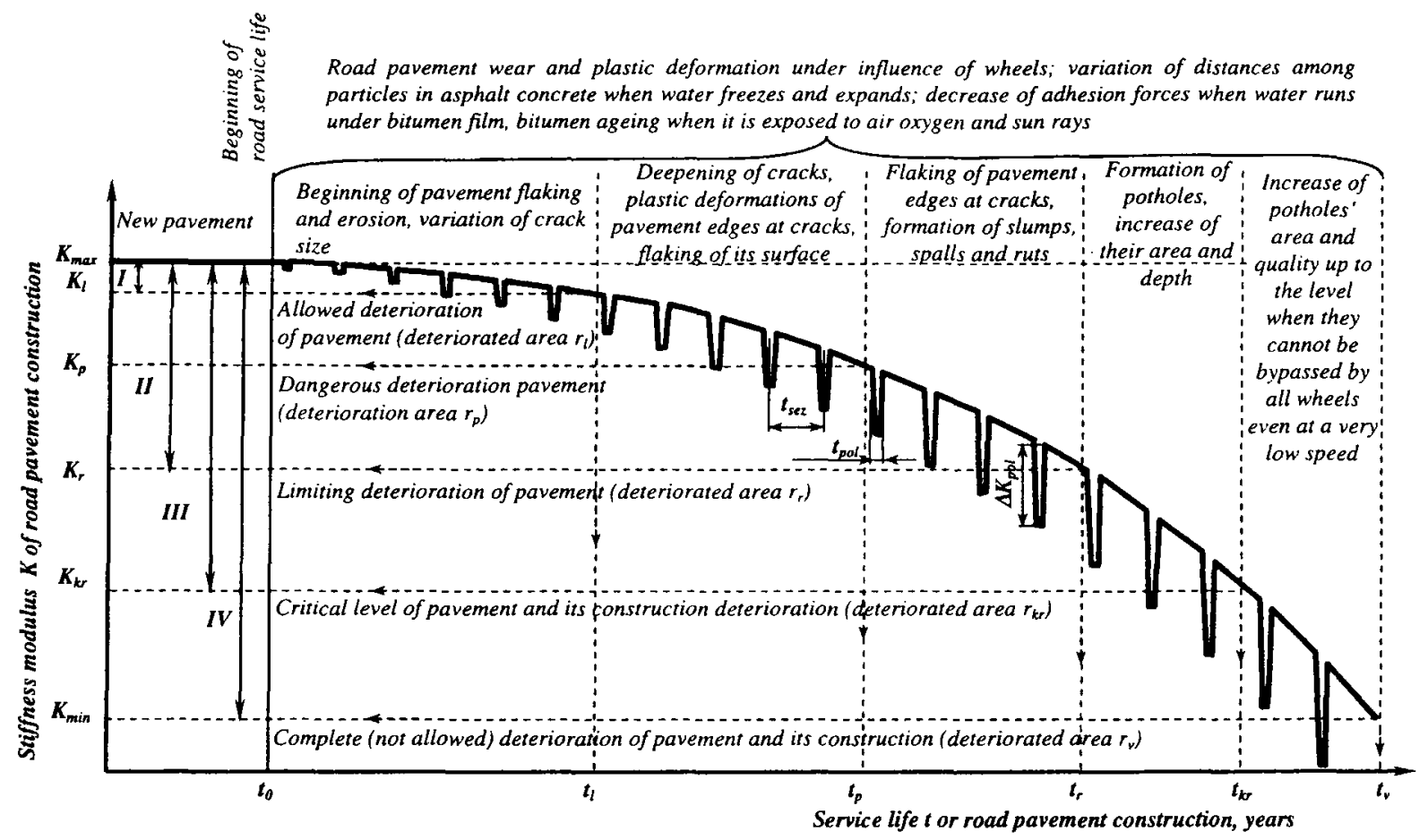

Fig 2. Dynamics of asphalt concrete pavement and its structural strength reduction when irremediable defects develop

When road pavement asphalt concrete is loaded mechanically, the following typical complex characteristics become visible: elasticity, plasticity, resilience, stress relaxation; when deformation speed changes, the change of its strength, accumulation of deformations at multiple extremely frequent loading, etc form.

When asphalt concrete pavement is impacted by vehicle loads, stresses occur. Pavement cracks when the tension of stretching reaches and exceeds the strength of pavement at stretching. Road pavement tensions are as follows:

- tension of stretching $\sigma_{t}$ of temperature type due to the inability of contracting pavement to move when cooling,

- tension due $\sigma_{p}$ to inhomogeneously risen cooled ground of embankment under pavement at negative temperatures of air and soil,

- tension of resilience and shear $\sigma_{\breve{s l}}$ due to decceleration and acceleration of vehicles,

- periodic tension $\sigma_{1}$ of resilience due to vertical pressure of vehicle wheels on pavement.

Tension of temperature type occurs in road structures functioning under conditions when loose movements are impossible when pavement freezes at $\Delta T$; whereas at linear state of tension temperature type tensions $\sigma_{t}$ occur which are estimated as follows [10]:

$$
\sigma_{t}=E_{1}\left(\alpha_{a}-\alpha_{0}\right) \Delta T,
$$

and at volumetric tension

$$
\sigma_{t}=\begin{gathered}
E_{1}\left(\alpha_{a}-\alpha_{0}\right) \Delta T \\
1-C_{x} \mu
\end{gathered}
$$

here $E_{1}, \alpha_{a}, \mu$ are asphalt concrete elasticity modulus, linear (temperature type) expansion coefficient, Poisson's ratio; $\alpha_{0}$ - linear (temperature type) expansion coefficient of base material; $C_{x}$ - coefficient the values of which are 0,1 or 2 depending if restrictions imposed on the freely deforming material are one-, two-, or threedirectional (for asphalt concrete which functions at the flat state, the value $C_{x}$ could be more than 0 when the road pavement is very wide).

Since $\alpha_{a}$ and $\alpha_{0}$ differ considerably at the beginning of winter, especially when asphalt concrete pavement cools immediately, tension of resilience $\sigma_{t}$ considerably exceeds its strength to resilience and the pavement cracks. When the pavement ages, its elasticity decreases, tension of resilience constantly increases, and the number of cracks and width become larger.

When pavement or its surface cracks, these defects develop further. Potholes appear in places of impact deformation loads when vehicles are driven, which not only influence the traffic safety and driving comfort but also reduce the driving speed [11-19].

\section{The condition of Lithuanian road asphalt concrete pavement}

According to the research carried out in Eastern Europe, the condition of Lithuanian road pavement is 
very good; however, if our road pavement is assessed according to the requirements of Western Europe, its condition is satisfactory. In 1998, pavement roughness of $2 \%$ of road sections on the Lithuanian main roads was very poor (according to the international roughness index IRI was $>6 \mathrm{~m} / \mathrm{km}$ ), on national roads $-8 \%$ (in 1999 ), on roads renamed from regional to national $-12 \%$ [20]. The road pavement condition has been deteriorating lately, rutting has been developing especially quickly since the number of heavy multi-axle vehicles has increased considerably but the roads are not ready for this additional load in terms of their pavement strength and roughness. During this period, the volume of repair work carried out on roads has decreased considerably (Table 1) $[21]$

Table 1. Volume of repair work on roads of the Lithuanian Republic 1988-1998

\begin{tabular}{|l|c|c|}
\hline \multicolumn{1}{|c|}{ Type of repair } & \multicolumn{2}{|c|}{$\begin{array}{c}\text { Volume of repair work } \\
\text { in km per year }\end{array}$} \\
\hline $1988-1992$ & $1993-1998$ \\
\hline $\begin{array}{l}\text { Setting up or repair of } \\
\text { asphalt concrete pavement }\end{array}$ & 295 & 205 \\
\hline $\begin{array}{l}\text { Asphalt concrete pavement } \\
\text { surfacing }\end{array}$ & 1080 & 620 \\
\hline
\end{tabular}

The research [22] shows that the Lithuanian road pavement is slowly fatiguing due to the increase of defects (increase of deterioration level) and other causes mentioned above: structural number SNC, which defines the strength of road pavement construction, decreases by $2 \%$ on average, and in 2000 it decreased even by $3 \%$.

Our research [23] shows that asphalt concrete pavement homogeneity on roads Vilnius-Kaunas (A1), Kaunas-Klaipėda (A1), Vilnius-Panevėžys (A2) varies inconsiderably. The pavement deterioration level $D$ fluctuated from 0 to $14,01 \%$ on 25 sections of road VilniusKaunas (A1). Fatigue deterioration and deterioration due to insufficient strength of pavement structure part $D_{n}$ made up $14,77 \%$, erosion deterioration $D_{e}: 3,75 \%$ and temperature cracks $D_{t}: 81,48 \%$. Pavement deterioration level $D$ fluctuated from 0 to $39,78 \%$ on 35 sections of the motorway Kaunas-Klaipeda (Al). Parts $D_{n}, D_{e}$ and $D_{t}$ of separate deterioration types made up $39,89 \%$, $40,46 \%$ and $19,65 \%$, respectively. Pavement deterioration level fluctuated from 0 to $61,27 \%$ on 43 sections of the motorway Vilnius-Panevėžys (A2). Parts of deterioration types $D_{n}, D_{e}$ and $D_{t}$ were made up of $56,49 \%$, $22,10 \%$ and $21,41 \%$, respectively.

Our research findings [24] on the road VilniusKaunas (A1) and motorway Vilnius-Panevėžys (A2) show that there is a very close correlation between pavement quality indicators D and Y (Figs 3,4).

To identify the condition of the Lithuanian main roads and to present recommendations on planning their pavement repair works, road pavement roughness $Y$ shall be normalised.

Research [20] carried out by the Transport and Road Research Institute (hereinafter TRRI) shows that modern road construction technologies in Lithuania enable to achieve roughness of newly laid pavement according to IRI: $Y_{I R I}=1,8 \mathrm{~m} / \mathrm{km}$; whereas its roughness is worsening at $\Delta Y_{I R I}=0,092 \mathrm{~m} / \mathrm{km}$ each year when the same amount of funds is allocated as in last few years.

The Lithuanian Road Administration (LRA) has prepared specifications [25] which stimulate the allowed and limiting values of pavement roughness. When laying new road pavement, it is very important to ensure the allowed pavement roughness values, and when limiting roughness values are achieved, the pavement shall be repaired. Analysis of specifications [25] shows that asphalt concrete pavement roughness can change from the allowed $Y_{I R I}^{(l)} \leq 2,0 \mathrm{~m} / \mathrm{km}$ to limiting $Y_{I R I}^{(k)} \leq 3,0 \mathrm{~m} / \mathrm{km}$ during period due $T_{k}$ to the deterioration of pavement roughness when extensive repair of pavement structure shall be carried out:

$$
T_{k}=\frac{Y_{I R I}^{(k)}-Y_{I R I}^{(I)}}{\Delta Y_{I R I}} .
$$

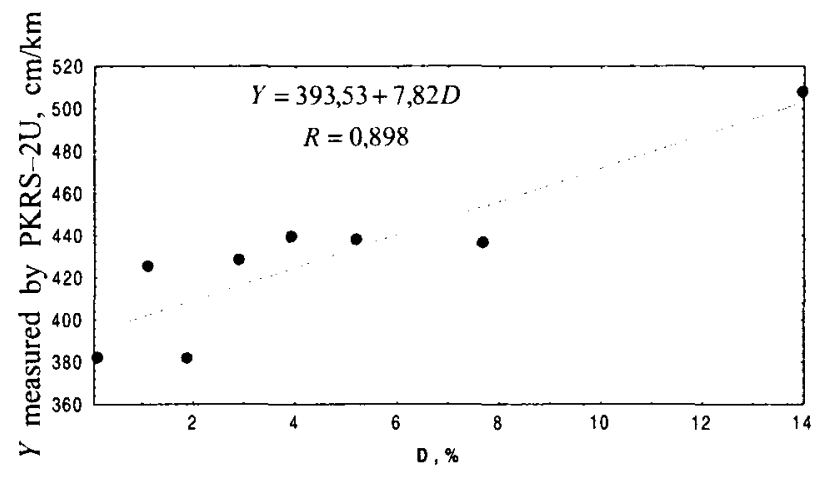

Fig 3. Dependence of pavement deterioration level $D$ on roughness $Y$ on the road Vilnius-Kaunas (A1)

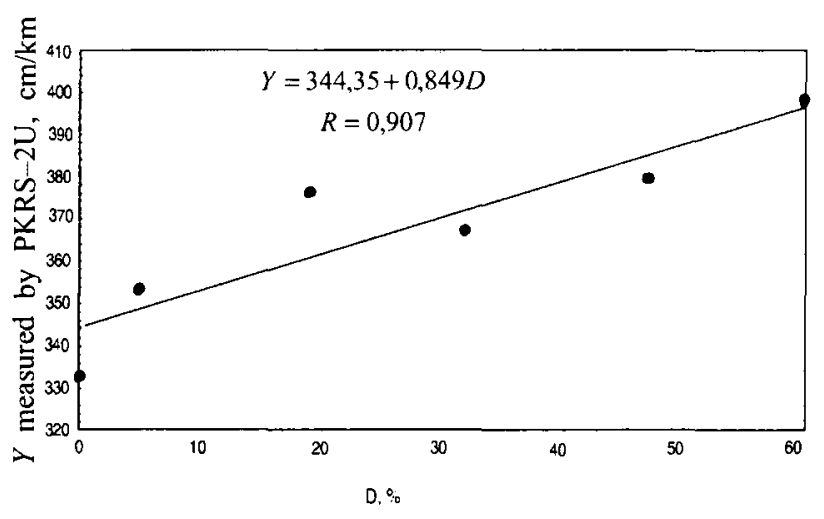

Fig 4. Dependence of pavement deterioration level $D$ on roughness $Y$ on the motorway Vilnius-Panevėžys (A2) 
In case of our analysis $T_{k}=\frac{3,0-2,0}{0,092}=10,87$ years. TRRI research data [20] show that when road pavement roughness deteriorates according to IRI from $Y_{I R I}=2,0 \mathrm{~m} / \mathrm{km}$ to $Y_{I R I}=2,5 \mathrm{~m} / \mathrm{km}$, transport costs $I$ to drive $1 \mathrm{~km}$ for 1000 vehicles increase from $I=724 \mathrm{LT}$ to $I=736 \mathrm{LT}$, ie increase by $1,66 \%$, and when pavement roughness worsens according to IRI from $Y_{I R I}=2,0 \mathrm{~m} / \mathrm{km}$ to $Y_{I R I}=2,75 \mathrm{~m} / \mathrm{km}$, transport costs increase from $I=724 \mathrm{LT}$ to $I=742 \mathrm{LT}$, ie increase by $2,49 \%$ (Fig 5).

When pavement roughness decreases according to IRI from $Y_{I R I}=3,0 \mathrm{~m} / \mathrm{km}$ to $Y_{I R I}=3,5 \mathrm{~m} / \mathrm{km}$, an average speed of vehicle flow decreases from $v=90 \mathrm{~km} / \mathrm{h}$ to $v=89 \mathrm{~km} / \mathrm{h}$ [20], ie inconsiderably (Fig 6).

We recommend to consider value $Y_{I R I}=2,5 \mathrm{~m} / \mathrm{km}$ of Lithuanian motorways asphalt concrete roughness according to IRI criterion when estimating the time span from pavement construction service life until its average repair $T_{v}$, and roughness value $Y_{I R I}=2,75 \mathrm{~m} / \mathrm{km}$ shall be considered a criterion when estimating the time span from pavement structure service life until extensive repair $T_{k}$. In the recommended case $T_{v}$ and $T_{k}$ :

$$
\begin{gathered}
T_{v}=\begin{array}{c}
Y_{I R I}^{(k)}-Y_{I R I}^{(l)} \\
\Delta Y_{I R I}
\end{array}=\begin{array}{c}
2,5-2,0 \\
0,092
\end{array} \approx 5,5 \text { years, } \\
T_{k}=\frac{Y_{I R I}^{(k)}-Y_{I R I}^{(l)}}{\Delta Y_{I R I}}=\frac{2,75-2,0}{0,092} \approx 8,0 \text { years. }
\end{gathered}
$$

When less rough asphalt concrete pavement is laid, for example, when roughness value according to IRI $Y_{I R I}=1,8 \mathrm{~m} / \mathrm{km}$ is reached, the actual service life of pavement $T_{v}$ and $T_{k}$ structure if compared to the recommended, normalized life could be prolonged by 2 years respectively.

When assessing asphalt concrete pavement roughness on motorways which was laid earlier, the following roughness values $Y$ shall be considered critical: $Y_{I R I}=3,5 \mathrm{~m} / \mathrm{km}, Y_{P K R S-2 U}=350 \mathrm{~cm} / \mathrm{km}$. These are val-

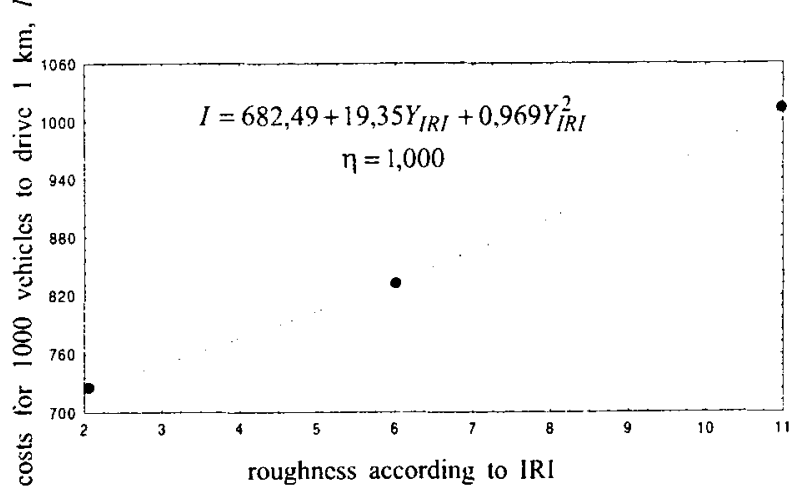

Fig 5. Interdependence of flatness $Y_{I R I}$ of a road covering and transport charges $I$

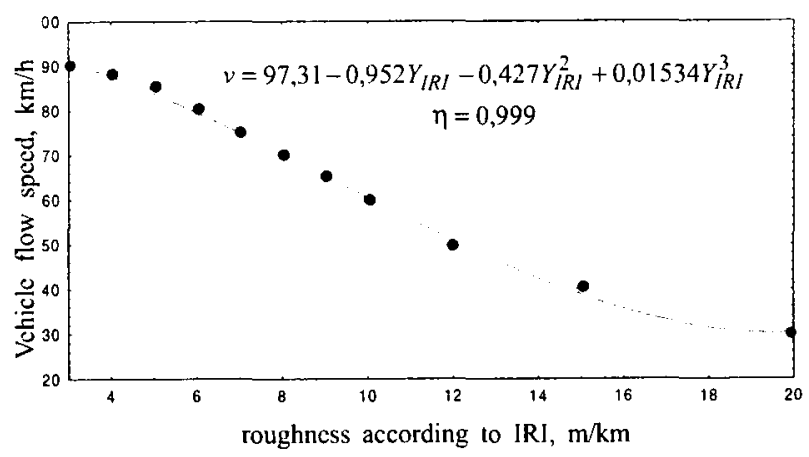

Fig 6. Dependence of vehicles speed $v$ on road pavement roughness $Y_{I R I}$

ues when average pavement repair shall be carried out, and $Y_{I R I}=3,75 \mathrm{~m} / \mathrm{km}, Y_{P K R S-2 U}=375 \mathrm{~cm} / \mathrm{km}$ are values when it is necessary to carry out extensive repair of pavement structure.

Critical levels of asphalt concrete pavement roughness of motorways as well as rational values $T_{v}$ of pavement and its $T_{k}$ structure service life to average and extensive repairs are presented in Table 2 .

Table 2. Recommended allowable values of parameters of Lithuanian motorways asphalt concrete pavement and its condition

\begin{tabular}{|l|c|c|}
\hline \multirow{2}{*}{$\begin{array}{c}\text { Indicator road pavement and its } \\
\text { structure condition and its } \\
\text { measurement } \ldots\end{array}$} & Allowed values of indicator \\
\cline { 2 - 3 } & for pavement set up in 1998 and later & for pavement set up in 1997 and earlier \\
\hline $\begin{array}{l}\text { Roughness } Y_{P K R S \cdot 2 U}, \mathrm{~cm} / \mathrm{km}: \\
\text { before interim repair } \\
\text { before overhaul }\end{array}$ & - & $\leq 350$ \\
\hline $\begin{array}{l}\text { Roughness } Y_{I R I}, \mathrm{~m} / \mathrm{km:} \\
\text { before interim repair } \\
\text { before overhaul }\end{array}$ & - & $\leq 375$ \\
\hline $\begin{array}{l}\text { Service life } T, \text { years: } \\
\text { before interim repair } \\
\text { before overhaul }\end{array}$ & $\leq 2,75$ & $\leq 3,50$ \\
\hline
\end{tabular}


When using rational values of motorways pavement roughness and service life recommended in Table 2 , costs of pavement and its repair can be planned efficiently.

\section{Conclusions}

1. Due to inhomogeneity of materials characteristics and the stochastic nature of asphalt concrete mixture production as well as changes of its laying technological process operation parameters, composition, structure and strength of laid asphalt concrete pavement in various road pavement spots varies considerably and slightly. High inhomogeneity of pavement strength determines its insufficient dependability due to rapid deterioration of its weakest sections. Cracking, peching, flaking, flaking of pavement edges, potholes, sliding, rutting, landsliding and other defects deteriorate road exploitation properties. If these defects are not removed, they increase according to the model presented in Fig 2; therefore, road pavement reaches critical values.

2. When maintaining road asphalt concrete pavement under operation, in most cases the results of its deterioration but not the causes of defects are eliminated. Thus in such cases new defects appear in the areas adjacent to the repaired ones. Consequently, deformations and defects (deterioration) of road pavement and its structure increase constantly accelerating and increasing the total area of repaired and unrepaired sections of deteriorating pavement.

3. Road pavement deformations and defects develop due to rapid shrinking of the material (cracking) or separation of its bigger or smaller pieces from monolith (wearing, peching, flaking, flaking of pavement edges, potholes). To correct these defects, new materials which fill in the space of opened gaps or flaking layers, are used in addition. To correct defects, the same type of material as road pavement shall be used, for example, asphalt concrete pavement shall be repaired with asphalt concrete mixture or bitumen mastic but not with cement concrete mixture.

4. Our research showed that road pavement deterioration level $\mathrm{D}$ is closely connected with asphalt concrete roughness $\mathrm{Y}$. When recommended rational values of motorway pavement roughness and service life are used, costs allocated for pavement and its construction repair can be planned effectively.

\section{References}

1. Lefort M. Cold on-site recycling of old pavements: a survey of the technique. In: Bridge and road laboratory bulletin (Bulletin des laboratories des ponts et chaussées. LCPC), 1997 nov. - dec. No 212, p 5-23 (in French).

2. El Hussein H. M., Kim K. W., Ponniah I. Asphalt concrete damage associated with extremely low temperatures. Journal of Materials in Civil Engineering. ASCE, 1998 nov. Vol 10, No 4, p 269-274.

3. Li G., Li Y., Metcalf J. B., Pang S.-S. Elastic modulus prediction of asphalt concrete. Journal of Materials in
Civil Engineering. ASCE, 1998 Aug. Vol 11, No 3, p 236-241.

4. Lee H.-I., Daniel I. S., Kim Y. R. Continuum damage mechanics - based fatique model of asphalt concrete. Journal of Materials in Civil Engineering. ASCE, 2000 May. Vol 12, No 2, p 105-112.

5. Al-Suleiman T. I., Obaidat M. T., Abdul-Iabar G. T., Khedaywi T. S. Tield inspection and laboratory testing of highway pavement rutting. Can. I. Civ. Eng. NRC Canada, 2000, Vol 27, p 1109-1119.

6. Ferraro Maia A., Vivien N., Udron I. Influence of bitumen content and grade on the structural behaviour of an asphaltic concrete. In: Road and airport general review (Révue gênerale des routes et des aêrodromes). 1986 mars, 628, p 44-48 (in French).

7. Petkevičius $\mathrm{K}$. Maintenance periods of road asphalt concrete pavement and its setting method. City development and roads: Supplement of Journal Civil Engineering (Miestu plètra ir keliai. Mokslo žurnalo „Statyba“" priedas). Vilnius: Technika, 2000, p 44-48 (in Lithuanian).

8. Nosov V. P. Road pavement destruction forecasting principles. Science and engineering in road building (Наука и техника в дорожной отрасли), № 2(17), 2001, р 24 27 (in Russian).

9. Citovich N. A. Soil mechanics. Manual for higher civil engineering schools (Механика грунтов. Учебник для строит. вузов). Moscow: Higher school, 1983. 288 p (in Russian).

10. Pechionii B. G. Bitumen and bitumen composition (Битумы и битумные композиции). Moscow: Chemistry, 1990. 256 c. (in Russian).

11. Bennett C. R., Patersen W. D. O. HDM-4. Vol 5. A Guide to Calibration and Adaptation. PIARC, 1999. $198 \mathrm{p}$.

12. Petkevičius K., Sivilevičius H. Required properties of road asphalt concrete pavement and its rational service life. Transport Engineering (Transportas), Vol XV, No 4, Vilnius: Technika, 2000, p 184-195 (in Lithuanian).

13. Kretov V. A., Kramer E. L., Rudenskij A. V. Reflected formation of fractures on asphalt concrete pavements. Science and engineering in road building (Наука и техника в дорожной отрасли), No 1(4), 1998, р 3-6 (in Russian).

14. Sivilevičius H. Influence of tranzit traffic upon asphalt concrete pavement lifetime. Transport Engineering (Transportas), No 2(15), 1997, p 38-44 (in Lithuanian).

15. Kiriuchin G. N. Residual strains in asphalt pavements. Science and engineering in road building (Наука и техника в дорожной отрасли), № 3(6), 1998, р 14-16 (in Russian).

16. Bakhrakh G. S. Estimation of strengthening of flexible road pavements according to fatique cracking criterion. Science and engineering in road building (Наука и техника в дорожной отрасли), № 2(9), 1999, р 21-25 (in Russian).

17. Kazarnovskij V. D. Rutting problem on roads with asphalt concrete pavement. Science and engineering in road 
building (Наука и техника в дорожной отрасли), No 2(13), 2000, p 3-4 (in Russian).

18. Kasatkin J. N. Forecasting of crack resistance on asphaltconcrete pavements. Science and engineering in road building (Наука и техника в дорожной отрасли), No 3(14), 2000, p 16-18 (in Russian).

19. Koganzon M. S., Jakovlev J. M. Theory and estimation methods of flexible road pavements. Science and engineering in road building (Наука и техника в дорожной отрасли), No $4(15), 2000$, p 22-23 (in Russian).

20. Road fund justification for $2000 /$ Internediate report of TRRI research work (Keliu fondo pagrindimas 2000 metams / TKTI tyrimo darbo tarpiné ataskaita). Kaunas, 1999. $44 \mathrm{p}$ (in Lithuanian).

21. Puodžiukas V., Domatas A. Lithuanian road budget is satisfying only a part of the existing needs. Lithuanian roads (Lietuvos keliai). 1999/1. Vilnius, AB "Vilpsta", 1999, p 14-19 (in Lithuanian).

22. Puodžiukas V. Investigation of asphalt concrete road pavement condition and the need for pavement strengthening of Lithuanian roads (Asfaltbetonio dangụ büklès tyrimai ir stiprinimo poreikis Lietuvos keliuose). Doctoral thesis: technical sciences, civil engineering (7I). Vilnius, 1999. $115 \mathrm{p}$ (in Lithuanian)

23. Petkevičius K. Methodology of setting road maintenance periods / Research work report (Metodikos automobiliy keliu tarpremontiniams laikotarpiams nustatyti sukūrimas / Mokslo tyrimo darbo ataskaita). Vilnius, 1999. $116 \mathrm{p}$ (in Lithuanian).

24. Petkevičius K. Analysis of road asphalt pavement rehabilitation methods and selection of rational methods / Research work report (Automobiliu kelių asfaltinès dangos taisymo metody analize ir racionalaus taisymo metodo parinkimas / Mokslo tyrimo darbo ataskaita). Vilnius, 2001. 160 p (in Lithuanian).

25. Requirements for approval of work, monetary deductions and self-control tests / LRA (Darbụ prièmimo, piniginiu išskaitymų bei savikontrolès bandymu reikalavimai / LAKD). Vilnius, 1996. $24 \mathrm{p}$ (in Lithuanian). 